\title{
Antioxidant effectiveness of dehydrogenated $p$-phenylene diamines through NMR calculations
}

\author{
Ingrid Puškárová, Martin Breza \\ Institute of Physical Chemistry and Chemical Physics, Faculty of Chemical and Food Technology, \\ Slovak University of Technology, SK-81237 Bratislava, Slovak \\ ingrid.puskarova@stuba.sk
}

\begin{abstract}
NMR shifts of N-phenyl-N'-alkyl-p-phenylenediamines (PPD) in vacuum were evaluated by B3LYP calculations using GIAO method. According to our previous studies, the Molar Antioxidant Effectiveness (AEM) of PPD antioxidants correlates with NMR chemical shifts of the amine nitrogen between aromatic rings $\left(\mathrm{N}_{\mathrm{A}}\right)$, the side aliphatic chain nitrogen $\left(\mathrm{N}_{\mathrm{B}}\right)$ and its neighboring tertiary carbon atom $\left(\mathrm{C}_{\mathrm{T}}\right)$ as well as of the hydrogens bonded to them. Our results indicate that the above mentioned chemical shifts correlate with increasing reactivity of dehydrogenated PPD antioxidants at these sites as well.
\end{abstract}

Keywords: NMR shifts, antioxidants, quantum-chemical calculations, antioxidant effectiveness, dehydrogenation

\section{Introduction}

The rate of the oxidative degradation of organic materials which are exposed to oxygen can be reduced using antioxidants (Aox). Aromatic secondary amines, particularly N-phenyl-N'-alkyl-pphenylenediamines (PPD) are the most important commercial antioxidants used prevailingly in rubber industry (Cataldo, 2001; Cataldo, 2002). The most important reactive radical intermediates formed during degradative reactions are hydroxyl $(\mathrm{HO} \bullet)$, alkoxyl $(\mathrm{RO} \bullet)$ and peroxyl $(\mathrm{ROO} \bullet)$ radicals which can readily abstract hydrogen atoms from polymer molecular backbones, ultimately breaking down the polymer molecules. The supposed mechanism of inhibition by phenylenediamines consists of several steps. Reaction products of primarily formed amine radicals are benzoquinonediimines and nitroxyl radicals, which have antioxidative effects as well (the benzoquinonediimines due to the subsequent regeneration of the nitroxyl trapping species). The benzoquinonediimine-type products may finally undergo hydrolytic or condensation reactions by forming benzoquinonemonoimine-type structures or N-heterocyclic compounds (Cataldo, 2001; Cataldo, 2002).

Simon et al. investigated the relation between the structure of the PPD antioxidants and their efficiency in polyisoprene rubber (PIR) by non-isothermal DSC (Differential Scanning Calorimetry) measurements (Cibulková, 2005a; Cibulková, 2005b; Polovková, 2006; Gatial, 2007; Cibulková, 2009; Rapta, 2009; Cibulková, 2010; Cibulková, 2012; Černá, 2012). As the concentration of free radicals during the induction period determines the rate of the oxidation reaction, which can be reduced using antioxidants, the antioxidant activity can be evaluated as the ratio of the lengths of the induction periods $t_{i}$ of the stabilized (PIR $+\mathrm{AOx}$ ) and unstabilized (PIR) polymer since the stability or non-stability of the polymer is brought about the same structural units both in stabilized and unstabilized polymer.

The protection factor, $P F$, is defined as

$$
P F=\frac{t_{i}(P I R+A O x)}{t_{i}(P I R)}
$$

The greater is the value of $P F$, the higher is the antioxidant effectiveness of the additive.

The values of protection factors decrease with increasing temperature and decreasing concentration of the antioxidant. As the dependence of protection factor on the antioxidant concentration is almost linear, the Molar Antioxidant Effectiveness (AEM) can be defined as

$$
A E M=\frac{P F-1}{m}
$$

where $m$ is the concentration of antioxidant in polymer matrix expressed in mol $\mathrm{kg}^{-1}$.

Simon et al. (Cibulková, 2005a; Cibulková, 2005b; Polovková, 2006; Gatial, 2007; Cibulková, 2009; Rapta, 2009; Cibulková, 2010; Cibulková, 2012; Černá, 2012) have found that the effectiveness of a series of antioxidants under study is indirectly proportional to the dissociation energy of the $\mathrm{C}-\mathrm{H}$ bond at the tertiary carbon atom in the neighbourhood of the nitrogen atom. Substitution of all hydrogen atoms at this carbon atom leads to a loss of antioxidant properties. This fact leads to 


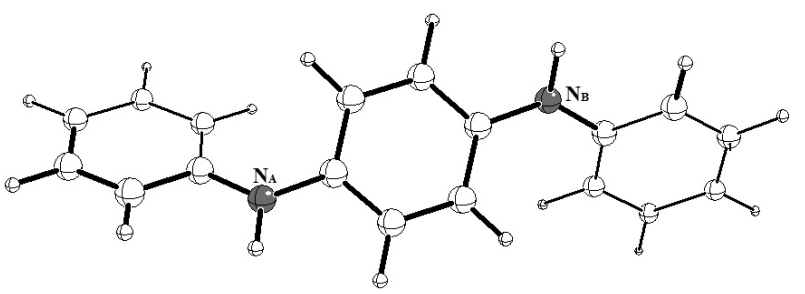

Fig. 1. Optimized structure of N,N'-diphenylp-phenylenediamine (DPPD).

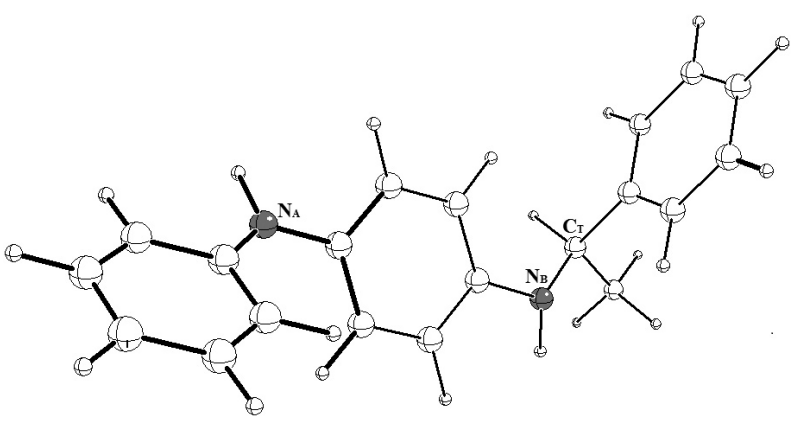

Fig. 2. Optimized structure of N-phenyl-N'(1'-methylbenzyl)-p-phenylenediamine (SPPD).

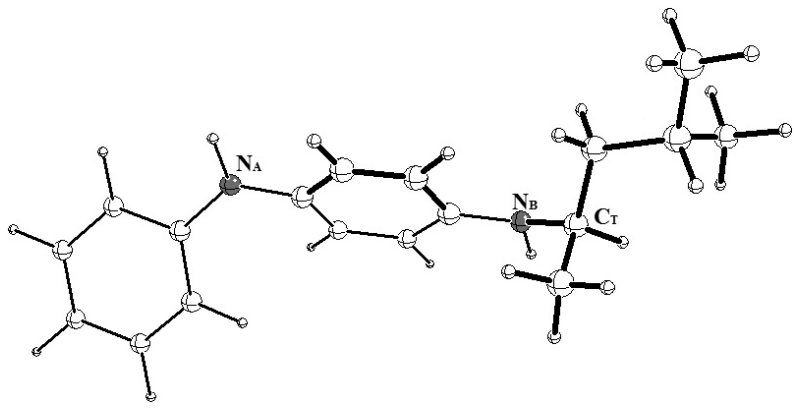

Fig. 3. Optimized structure of N-phenyl-N'(1,3-dimethyl-butyl)- $p$-phenylenediamine (6PPD).

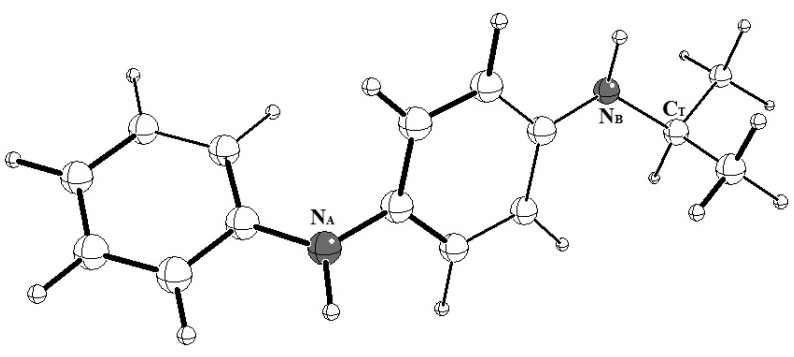

Fig. 4. Optimized structure of N-phenyl-N'isopropyl- $p$-phenylenediamine (IPPD).

a justifiable assumption that, in the mechanism of antioxidation effect of PPDs, instead of the classical benzoquinonediiminetype structure<smiles>[R]C([R])N=C1C=CC(=Nc2ccccc2)C=C1</smiles>

the ketimine molecule should be included:

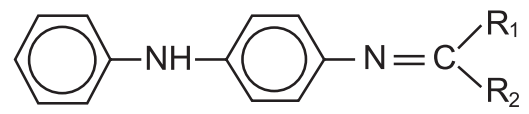

where $R_{1}$ and $R_{2}$ are substituents.

In order to find the relation between the structures of PPD antioxidants and their $A E M$ values some of them were investigated theoretically by Density Functional Theory (DFT) model studies as well (Polovková, 2006; Gatial, 2007; Rapta, 2009; Kortišová, 2005; Breza, 2006; Breza, 2008; Rimarčík, 2010). Real PPD structures in the protected materials significantly depend on solid state effects and so it is very problematic to find suitable characteristics of the PPD molecules which not much depend on their conformations. In our previous study (Puškárová, 2015) we have investigated experimentally and evaluated by B3LYP calculations the NMR shifts of several PPD antioxidants in DMSO. We have found that their $A E M$ increases with NMR shifts of both amine hydrogens, of the nitrogen between aromatic rings and probably of the tertiary carbon atom neighboring to the nitrogen between aromatic ring and the side aliphatic chain in agreement with the above mentioned theory of Simon et al. (Cibulková, 2005a; Cibulková, 2005b; Polovková, 2006; Gatial, 2007; Cibulková, 2009; Rapta, 2009; Cibulková, 2010; Cibulková, 2012; Černá, 2012). On the other hand, the NMR shifts of the amine nitrogens between aromatic ring and the side aliphatic chain exhibit a reverse trend. This is very surprising because similar reactions at both nitrogen sites are supposed.

In our recent study (Puškárová, 2016) we have shown that the experimental and calculated NMR shifts of the atoms $\mathrm{N}, \delta \mathrm{N}_{\mathrm{A}}$ and $\delta \mathrm{N}_{\mathrm{B}}$, and neighbouring tertiary carbon atom $\mathrm{C}, \delta \mathrm{C}_{\mathrm{T}}$, in the PPD antioxidants correlate with their Molar Antioxidant Effectiveness (AEM). So we decided to apply this approach to their dehydrogenation products.

\section{Method}

Standard B3LYP/6-311G* geometry optimizations of DPPD, SPPD, 6PPD and IPPD neutral molecules (see Figures 1-4) in singlet spin states performed using GAUSSIAN03 program package (Frisch, 2003) were taken from Ref. (Puškárová, 2016). Starting from the same stable structures and using the standard geometry optimization method we have obtained their single, double and triple dehydrogenation products after splitting neutral hydrogen radicals from the atoms $\mathrm{N}_{\mathrm{A}}, \mathrm{N}_{\mathrm{B}}$ and/or neighboring tertiary $\mathrm{C}_{\mathrm{T}}$ atom in their lowest ground spin states. Stability of the optimized structures was confirmed by vibrational analysis (no imaginary vibrations). Absolute 
shieldings, $\sigma \mathrm{X}$, of individual atoms $\mathrm{X}$ were calculated by the Gauge-Independent Atomic Orbital (GIAO) method (Wolinski, 1990) at B3LYP/6-311++G** level of theory. NMR shifts, $\delta \mathrm{X}$, relative to tetramethylsilane (for $\mathrm{X}={ }^{1} \mathrm{H}$ and ${ }^{13} \mathrm{C}$ ) and $\mathrm{CH}_{3} \mathrm{NO}_{2}\left(\right.$ for $\mathrm{X}={ }^{15} \mathrm{~N}$ ) were evaluated in analogy with (Blanco, 2007; Silva, 2008) from the relation (3)

$$
\delta X=a_{0}+a_{1} \sigma(X)
$$

Parameters $a_{0}, a_{1}$ were taken from Ref. (Puškárová, 2016) for vacuum.

\section{Results and discussion}

In agreement (except SPPD) with our previous study (Breza, 2006) the values of the DFT energy $\left(\mathrm{E}_{\mathrm{DFT}}\right)$ imply that the first dehydrogenation is the most preferred (advantegous) at $\mathrm{N}_{\mathrm{A}}$ site, whereas doubly dehydrogenation is the most preferred at $\mathrm{N}_{\mathrm{B}}$ and $\mathrm{C}_{\mathrm{T}}$ sites (values in bold, see Table 1 ).

Dehydrogenation at $\mathrm{N}_{\mathrm{A}}, \mathrm{N}_{\mathrm{B}}$ or $\mathrm{C}_{\mathrm{T}}$ sites moves their chemical shifts to higher values which may be related with increasing reactivity of the radical. Dehydrogenation at the neigboring site causes a smaller positive change of the chemical shift. This change decreases with the distance from the dehydrogenation site and can be even negative. $\delta \mathrm{N}_{\mathrm{B}}$ is more shifted for the dehydrogenation at $\mathrm{C}_{\mathrm{T}}$ site than at $\mathrm{N}_{\mathrm{A}}$ site.

Before dehydrogenation is $\delta \mathrm{N}_{\mathrm{A}}>\delta \mathrm{N}_{\mathrm{B}}$ whereas for the radicals formed after the first dehydrogenation in the $\mathrm{C}_{\mathrm{T}}$ position the opposite relation is valid. After third dehydrogenation again $\delta \mathrm{N}_{\mathrm{A}}>0>\delta \mathrm{N}_{\mathrm{B}}$. Maximum value of the chemical shift $\delta \mathrm{X}$ after the third dehydrogenation is reached only for $\mathrm{X}=\mathrm{N}_{\mathrm{A}}$ and $\mathrm{C}_{\mathrm{T}} . \delta \mathrm{N}_{\mathrm{B}}$ achieves maximum value already in the first dehydrogenation step.

Tab. 1. Notation, DFT energies $\left(\mathrm{E}_{\mathrm{DFT}}\right)$ and chemical shifts $(\delta \mathrm{X})$.

\begin{tabular}{|c|c|c|c|c|c|c|c|c|}
\hline \multirow{2}{*}{ Acronym } & \multirow{2}{*}{ Symbol } & \multicolumn{3}{|c|}{ Site X } & \multirow{2}{*}{$\mathrm{E}_{\mathrm{DFT}}[$ hartree] } & \multicolumn{3}{|c|}{ Chemical shift $\delta \mathrm{X}[\mathrm{ppm}]$} \\
\hline & & $\mathrm{N}_{\mathrm{A}}$ & $\mathrm{N}_{\mathrm{B}}$ & $\mathrm{C}_{\mathrm{T}}$ & & $\mathrm{N}_{\mathrm{A}}$ & $\mathrm{N}_{\mathrm{B}}$ & $\mathrm{C}_{\mathrm{T}}$ \\
\hline \multirow[t]{4}{*}{ DPPD } & $\mathrm{D}(\mathrm{HH})$ & $\mathrm{H}$ & $\mathrm{H}$ & - & -805.26395 & -291.86 & -291.86 & - \\
\hline & $\mathrm{D}(0 \mathrm{H})$ & $\bullet$ & $\mathrm{H}$ & - & -804.62655 & 13.78 & -278.96 & - \\
\hline & $\mathrm{D}(\mathrm{H} 0)$ & $\mathrm{H}$ & - & - & -804.62655 & -278.96 & 13.80 & - \\
\hline & $\mathrm{D}(00)$ & $\bullet$ & - & - & -804.01174 & 15.52 & 15.53 & - \\
\hline \multirow[t]{8}{*}{ SPPD } & $\mathrm{S}(\mathrm{HHH})$ & $\mathrm{H}$ & $\mathrm{H}$ & $\mathrm{H}$ & -883.91013 & -296.30 & -302.28 & 51.48 \\
\hline & $\mathrm{S}(\mathrm{OHH})$ & - & $\mathrm{H}$ & $\mathrm{H}$ & -883.27364 & 7.66 & -290.93 & 50.48 \\
\hline & $\mathrm{S}(\mathrm{HOH})$ & $\mathrm{H}$ & - & $\mathrm{H}$ & -883.26680 & -277.99 & 41.20 & 57.22 \\
\hline & $\mathrm{S}(\mathrm{HH} 0)$ & $\mathrm{H}$ & $\mathrm{H}$ & $\bullet$ & -883.27144 & -293.10 & -267.60 & 95.41 \\
\hline & $\mathrm{S}(00 \mathrm{H})$ & • & $\bullet$ & $\mathrm{H}$ & -882.65499 & 10.22 & 33.84 & 56.56 \\
\hline & $\mathrm{S}(0 \mathrm{H} 0)$ & - & $\mathrm{H}$ & $\bullet$ & -882.64265 & -51.25 & -197.07 & 102.12 \\
\hline & $\mathrm{S}(\mathrm{H} 00)$ & $\mathrm{H}$ & - & - & -882.68923 & -291.14 & -22.71 & 137.09 \\
\hline & $\mathrm{S}(000)$ & $\bullet$ & - & - & -882.05001 & 27.28 & -19.74 & 138.18 \\
\hline \multirow[t]{8}{*}{$6 P P D$} & $6(\mathrm{HHH})$ & $\mathrm{H}$ & $\mathrm{H}$ & $\mathrm{H}$ & -810.09425 & -296.70 & -298.47 & 46.76 \\
\hline & $6(0 \mathrm{HH})$ & $\bullet$ & $\mathrm{H}$ & $\mathrm{H}$ & -809.45918 & 0.18 & -288.78 & 46.48 \\
\hline & $6(\mathrm{H} 0 \mathrm{H})$ & $\mathrm{H}$ & $\bullet$ & $\mathrm{H}$ & -809.44961 & -276.85 & 61.71 & 53.75 \\
\hline & $6(\mathrm{HH} 0)$ & $\mathrm{H}$ & $\mathrm{H}$ & $\bullet$ & -809.44834 & -294.92 & -263.24 & 83.53 \\
\hline & $6(00 \mathrm{H})$ & $\bullet$ & $\bullet$ & $\mathrm{H}$ & -808.83871 & 6.17 & 57.58 & 52.52 \\
\hline & $6(0 \mathrm{H} 0)$ & - & $\mathrm{H}$ & $\bullet$ & -808.82914 & -78.74 & -176.84 & 108.65 \\
\hline & $6(\mathrm{H} 00)$ & $\mathrm{H}$ & $\bullet$ & - & -808.88228 & -292.14 & -13.13 & 139.83 \\
\hline & $6(000)$ & $\bullet$ & $\bullet$ & $\bullet$ & -808.24309 & 27.45 & -11.69 & 141.02 \\
\hline \multirow[t]{8}{*}{ IPPD } & $\mathrm{I}(\mathrm{HHH})$ & $\mathrm{H}$ & $\mathrm{H}$ & $\mathrm{H}$ & -692.12939 & -296.76 & -294.97 & 41.13 \\
\hline & $\mathrm{I}(\mathrm{OHH})$ & $\bullet$ & $\mathrm{H}$ & $\mathrm{H}$ & -691.49389 & 2.99 & -282.64 & 41.26 \\
\hline & $\mathrm{I}(\mathrm{HOH})$ & $\mathrm{H}$ & - & $\mathrm{H}$ & -691.48713 & -278.96 & 43.40 & 49.59 \\
\hline & $\mathrm{I}(\mathrm{HH} 0)$ & $\mathrm{H}$ & $\mathrm{H}$ & - & -691.47682 & -294.28 & -263.91 & 80.89 \\
\hline & $\mathrm{I}(00 \mathrm{H})$ & • & • & $\mathrm{H}$ & -690.87589 & 6.72 & 46.21 & 49.52 \\
\hline & $\mathrm{I}(0 \mathrm{H} 0)$ & • & $\mathrm{H}$ & $\bullet$ & -690.85895 & -76.82 & -179.24 & 101.72 \\
\hline & $\mathrm{I}(\mathrm{H} 00)$ & $\mathrm{H}$ & $\bullet$ & - & -690.91073 & -292.44 & -16.43 & 137.06 \\
\hline & $\mathrm{I}(000)$ & $\bullet$ & $\bullet$ & $\bullet$ & -690.27158 & 27.81 & -14.01 & 137.74 \\
\hline
\end{tabular}


The formation the benzoquinonediimine-type structure (dehydrogenation at $\mathrm{N}_{\mathrm{A}}$ and $\mathrm{N}_{\mathrm{B}}$ sites) increases $\delta \mathrm{N}_{\mathrm{A}}$ values, but it need not increase $\delta \mathrm{N}_{\mathrm{B}}$ values. Nevertheless, the relation $\delta \mathrm{N}_{\mathrm{B}}>\delta \mathrm{N}_{\mathrm{A}}$ is preserved. The $\mathrm{N}_{\mathrm{B}}=\mathrm{C}_{\mathrm{T}}$ double bond formation (through dehydrogenations at both these sites) decreases the $\delta \mathrm{N}_{\mathrm{B}}$ value and increases the $\delta \mathrm{C}_{\mathrm{T}}$ value.

For the chemical shift changes at an $\mathrm{X}$ site after the first dehydrogenation step $(\Delta \delta \mathrm{X})$ the relation $\Delta \delta \mathrm{N}_{\mathrm{B}}>\Delta \delta \mathrm{N}_{\mathrm{A}}>\Delta \delta \mathrm{C}_{\mathrm{T}}$ is valid whereby $\delta \mathrm{N}_{\mathrm{B}}>\delta \mathrm{N}_{\mathrm{A}}$.

\section{Conclusions}

In this work, we have investigated antioxidant effectiveness of dehydrogenated $p$-phenylene diamines through NMR calculations. We have concluded that increasing values of the chemical shift $\delta \mathrm{X}$ might be related with the increasing reactivity at this site. The obtained results provided us valuable insight into the changes of the reactivity of the studied PPD antioxidants during dehydrogenation reactions and thus the most probable mechanism of their effect. Our results might be important for target syntheses of new more effective antioxidants as well as for further studies of the mechanism of their effect.

\section{Acknowledgement}

This work was supported by the Slovak Grant Agency VEGA under the contract no. 1/0598/16. We thank the HPC center at the Slovak University of Technology in Bratislava, which is a part of the Slovak Infrastructure of High Performance Computing (SIVVP Project No. 26230120002, funded by the European Region Development Funds), for computing facilities.

\section{References}

Blanco F, Alkorta I, Elguero J (2007) Magn. Reson. Chem. 45: 797-800.
Breza M, Kortišová I, Cibulková Z (2006) Polym. Degrad. Stab. 91: 2845-2852.

Breza M (2008) in Progress in Polymer Degradation and Stability Research (H. W. Moeller, Ed.), Nova Science Publ., New York, 2008; in New Research on Antioxidants (D. Marin and P. Garcia, Eds.), Nova Science Publ., New York.

Cataldo F (2001) Polym. Degrad. Stab. 72: 287-296.

Cataldo F (2002) Eur. Polym. J. 38: 885-893.

Černá A, Cibulková Z, Šimon P, Uhlár J, Lehocký P (2012) Polym. Degrad. Stab. 97: 1724-1729.

Cibulková Z, Šimon P, Lehocký P, Balko J (2005a) Polym. Degrad. Stab. 87: 479-486.

Cibulková Z, Šimon P, Lehocký P, Balko J (2005b) J. Therm. Anal. Calorim. 80: 357-361.

Cibulková Z, Šimon P, Lehocký P, Kosár K, Chochulová A (2009) J. Therm. Anal. Calorim. 97: 535-540.

Cibulková Z, Šimon P, Lehocký P, Kosár K, Uhlár J (2010) J. Therm. Anal. Calorim. 101: 679-684.

Cibulková Z, Černá A, Šimon P, Uhlár J, Kosár K, Lehocký P (2012) J. Therm. Anal. Calorim. 108: 1724-1729.

Frisch MJ, Trucks GW, Schlegel HB, Scuseria GE, Robb MA, Cheeseman JR et al. (2003) Gaussian 03, Revision. C1, Gaussian, Inc., Pittsburgh PA.

Gatial A, Polovková J, Kortišová I, Breza M (2007) Vibr. Spectrosc. 44: 1-8.

Kortišová I, Breza M, Šimon P (2005) J. Mol. Struct. (THEOCHEM) 723: 23-28.

Polovková J, Kortišová I, Gatial A, Breza M. (2006) Polym. Degrad. Stab. 91: 1775-1780.

Puškárová I, Šoral M, Breza M (2015) Chem. Phys. Lett. 639: 78-82.

Puškárová I, Breza M (2016) Polym. Degrad. Stab. 128: $15-21$.

Rapta P, Vargová A, Polovková J, Gatial A, Omelka L, Majzlík P, Breza M (2009) Polym. Degrad. Stab. 94: 1457-1466.

Rimarčík J, Lukeš V, Klein E (2010) J. Mol. Struct. (THEOCHEM) 44: 1-8.

Silva AMS, Sousa RMS, Jimeno ML, Blanco F, Alkorta I, Elguero J (2008), Magn.Reson. Chem. 46: 859-864.

Wolinski K, Hilton JF, Pulay P (1990) J. Am. Chem. Soc. 112: 8251-8260. 